\title{
Article
}

\section{Social work and digitalisation: bridging the knowledge gaps}

Taylor, Amanda M L

Available at http://clok.uclan.ac.uk/19489/

Taylor, Amanda M L (2017) Social work and digitalisation: bridging the knowledge gaps. Social Work Education, 36 (8). pp. 869-879. ISSN 0261-5479

It is advisable to refer to the publisher's version if you intend to cite from the work. http://dx.doi.org/10.1080/02615479.2017.1361924

For more information about UCLan's research in this area go to http://www.uclan.ac.uk/researchgroups/ and search for <name of research Group>.

For information about Research generally at UCLan please go to http://www.uclan.ac.uk/research/

All outputs in CLoK are protected by Intellectual Property Rights law, including Copyright law. Copyright, IPR and Moral Rights for the works on this site are retained by the individual authors and/or other copyright owners. Terms and conditions for use of this material are defined in the policies page.

\section{CLoK}

Central Lancashire online Knowledge www.clok.uclan.ac.uk

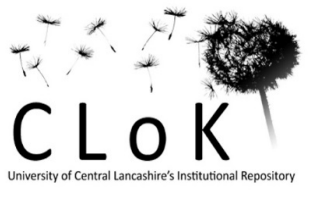




\title{
Social Work And Digitalisation: Bridging The Knowledge Gaps
}

\section{(Draft)}

\begin{abstract}
The aim of this paper is to spark a discussion about how social work in England has responded to digitalisation thus far. It pays attention to relationality, the interaction between people and things and includes reference to the practice landscape, the places and spaces within which social work occurs. It calls for social work to revisit the idea of professionalism in the connected age, through outlining circumstances where practitioners have been called to account for online practices that have compromised public trust. These practice failings indicate that knowledge gaps, pertaining to digital literacies and technological competence in social work education and practice, exist. Therefore, the current requirements for learning and development, pre and post qualification, are appraised alongside the preliminary findings of a research project designed to examine the contribution of social work education to the digital socialisation of students in readiness for practice (Taylor, 2015). The suggestion is made that social work should pause to consider 'digital knowledge gaps' before rushing to drive technology enhanced practice methods forward.
\end{abstract}

Keywords: digitalisation, digital literacy, digital professionalism, social work, social work education, technologies

\section{Digitalisation, social work and the practice landscape}

In the age of digitalisation, social work, like other professional groupings (Susskind and Susskind, 2015), is being challenged to think about its characteristics and form. Whilst a number of practices in social work have progressed, digital practices generally speaking have not, leaving the profession in many respects 'behind the curve' (Lightbody, 2015, p.ix,). The inevitability of technological innovation impacting further upon the practice domain should prompt social work to pause, and to consider its responses to digital developments thus far. Fundamental to this is the function of social work education and its role in the professional 
socialisation of students for practice. Literature and policy in England concerning social work education and practice amounts to a vast body of knowledge. Yet the same cannot be said of literature and policy pertaining to technologies in social work education and practice; where we find a knowledge base that is sporadic and sparse in comparison. Nevertheless, there is a clear and consistent theme throughout the literature that does exist, one that evidences the need for a more informed and pointed use of technologies in social work education, linked to practice and practice readiness (e.g. Rafferty, 1997; Cooner, 2010; Turner, 2016a). Yet what is concerning, is the lack of progress that appears to have been made (Rafferty and Waldman, 2006). Rafferty attributes this to a 'disjointedness' in social work education between how technologies are perceived, and how they are being used (2014, as cited in Westwood, 2014, p.xi). If this is the case, and the literature strongly suggests that it is, it raises important questions about how students are being equipped to practice in the digital age.

Digitalisation and its relationship to social work is multi-layered, fluid and complex, and as such must be understood in context. The context... that is the practice landscape, involves people, things and the places and spaces where social work occurs, and this now, more than ever, includes the digital. Significant to practice development is a recognition of the ways in which people are engaging with and experiencing the world. For social work in the connected age, it is the interrelatedness of people, places, spaces and things that needs reviewed. In an attempt to counter dominant discourse which describes people as somehow separate from technologies, and to make the point that 'the digital and physical [are in fact] enmeshed', Jurgenson (2012) coined the phrase 'digital dualism' (p.83). Jurgenson, a sociologist and social media theorist, stresses the dangers of focussing 'on one side, be it human or technology, without deeply acknowledging the other' (2012, p.84). Ballantyne (2015) agrees, and suggests 'Actor Network Theory' (ANT) (p.104) as a lens through which the interplay 
between people and technologies can be understood; given that it is 'unique in its recognition of the complex and tangled relationship between human and nonhuman actors' (p.114). Social work however, has had a 'troublesome' (Meyer and Land, 2003, p.1) and uneasy relationship with technology. Comments such as, 'I came into social work to work with people not computers' (Rafferty, 1997, p.964) are often still heard when information systems (IS) or technologies are being discussed or introduced. This type of 'digital dualism' (Jurgenson, 2012, p.83) is unhelpful because it fails to recognise the 'sociomaterial' (Fenwick, 2016. p.670) nature of the world, the profession, organisations and indeed the work. The relentless pace of digital innovation and its usage within modern life is triggering changes that cannot be ignored. Shifts, for social work, that mean

'whether we like it or not,... the need to demonstrate a critical awareness of the social impact of the internet, and a range of digital communication and information technologies, has never been more important than it is today' (Watling and Rogers, 2012, p.140).

Even though the majority of the lived experience occurs offline, digitalisation is forcing us online. The speed at which the UK Government's 'Digital by Default' strategy $(\mathrm{Gov}, 2016)$ is being implemented evidences how this is set to increase. Rust (2014), whilst attempting to outline the potential impacts of this digital shift, draws attention to the Government's 'Digital Efficiency Report' (Gov, 2012) which highlights how

'digital transactions are 20 times cheaper than by phone, 30 times cheaper than by post and as much as 50 times cheaper than by face-to-face meetings,'

resulting in a savings of ...

'between $£ 1.7$ and $£ 1.8 b n$ each year’ (np). 
The economic orientation of this data goes some way towards explaining the urgency of the 'Digital by Default' (Gov, 2016) agenda. Yet in direct conflict with this, are the findings of a more recent Government survey that revealed a significant deficit in digital literacy across the UK (ECORYS UK, 2016). Indeed, data drawn from the Office of National Statistics (ONS) shows that even though ' $88 \%$ ' of the general populace have engaged with online processes, ' $12 \%$ ' have not $(2016, \mathrm{np})$. Despite the fact that, numerically, $12 \%$ may not be regarded as concerning, it actually represents quite a significant proportion of the population, approximately 6 million people, to include 'many older and disabled people... and two-thirds of women over [the age of] 75' (Lee, 2016, as cited in ONS, 2016, np). Moreover, what this data fails to reflect is the reality for the people affected (ONS, 2016, np).

An hour and forty minutes spent engaging with social realism in the form of 'I Daniel Blake' (Bradshaw, 2016) illustrates in very real terms what 'Digital by Default' (Gov, 2016) can mean for those excluded. The main character, Daniel Blake, 'a man in his late 50's, who had worked all of his life as a carpenter' is described as an 'an honest bloke' (Laverty, 2016, p.147), who post the death of his wife suffers a heart-attack. The storyline follows Daniel as he navigates a set of circumstances that lead to him being 'sanctioned' (Adler, 2016, p.195; Taylor, 2017, np) and thus caught up in the tangled web that is the current benefits system. The occurrences that unfold drive Daniel into poverty. The stress associated with this experience cause Daniel to collapse at an appeal hearing, which was set to determine his future benefit entitlement.

Daniel died...

On the floor...

Of a public toilet...

In a Government building! 
Inasmuch as this work is fictive (Laverty, 2016), it accurately depicts the plight of an increasing percentage of society (Adler, 2016), through highlighting how defaulting to the digital can add to the marginalisation already felt by those attempting to access services. In addition, it illuminates the risks of placing economic value over human value in what once were welfare services.

Access to services and benefits are not the only areas relevant to social work influenced by the digital age (Harlow and Webb, 2001). The growth in social media type technologies means that existing problems are manifesting in ways that are becoming even more difficult to broach. Take for example, the issue of bullying in childhood. Prior to the emergence of the internet, bullying mainly occurred within the range of physical places children gathered to socialise (Wakefield, 2016). The raft of online spaces now available, for the purposes of socialising, has changed all of that. Children, of all ages, reside online and offline, and increasingly in both spaces simultaneously. Unsurprising therefore are statistics that show an '88\%' surge in bullying 'online' (NSPCC, 2016, p.7). The children interviewed in this NSPCC research spoke of the 'pressure' to get involved in 'sexting', and explained how they felt 'trapped because the bullies could reach them everywhere', with some describing how they had been taunted to take their own life (2016, p.7). It is the relentless nature of, and an inescapability from bullying that has reportedly led to a steep rise in the numbers of children committing suicide, highlighting the gravity of this issue in its current form (Whitehead, 2013; Pasha- Robinson, 2016). Similarly, with regards to sexual abuse, the UK National Crime Agency (NCA) reports an alarming increase in the use of new technologies by international crime groups to record, livestream and circulate material 'in exchange for payment' (2012, np). Misusing technologies in this way exacerbates the trauma associated 
with attacks of this type due to the scale of circulation made possible through the World Wide Web. This too, is and should be, cause for much concern.

Whilst the issues emerging, referred to in brief, are characteristic of those experienced prior to the connected age, the involvement of technologies creates additional dimensions that for social work require further thought. Hence, why it is the profession needs to become more digitally aware (Ogunyankin and Tudor, 2016; Peel and Shorrock, 2016). More attuned to how the choice to be online is being gradually eroded, and more critical of the subterfuge commonly used to deflect from the real impacts, for some, that the digital shift can have. That being said, it is unhelpful and misleading to deny or detract from the affordances of the connected age. However, before social work rushes to exploit these affordances and employ technologies to support and enhance learning and practice, it should first examine the preparedness of the workforce to respond to problems like those outlined above. Indeed, the actuality of digital knowledge gaps has become evident in recent years, with at least three practitioners (Schraer, 2014; Stevenson, 2014; McNicoll, 2016) and one student (Stevenson, 2016a) being called to account for their digital behaviours and presence online (Rettie, 2004). The problems arising relate to accountability, confidentiality and the compromise of public trust. All of which have led to questions relating to competence, suitability and professionalism more broadly. The reordering of the world, people and things, is driving the need for more digitally equipped professionals. As a consequence, it is time for digital literacy in social work to move beyond the skills to send an email or update computer based records, to more complex tasks that require an intricate and nuanced understanding of technologies and the connected world. 


\section{Bridging the knowledge gaps}

Across social work education and practice attention to digital professionalism is largely incidental, and the affordances of technologies, unrealised. Previous to very recent changes made to the requirements for social work education and practice (QAA, 2016; HCPC, 2017) the guidance that did exist (QAA, 2008; TCSW, 2013; HCPC, 2016) offered a modest amount of direction in terms of digital capabilities. The content of this guidance consisted of a number of concise and ambiguous statements that did little to highlight the significance of digital literacy as a layer of professionalism in social work (Turner, 2016b). In total, the requirements expected that 'honours graduates in social work ... [would] be able to use ICT methods and techniques to support their learning and their practice' (QAA, 2008, p.14). They prompted educators to think about how 'ICT skills ... [could] be taught as core skills, or integrally in other curriculum areas' (TCSW, 2013, p.1), and urged students to 'use all forms of communication appropriately and responsibly, including social media and networking websites' (HCPC, 2016, p.11). Inasmuch as this guidance existed, there remained a distinct lack of explicit reference to digital professionalism across the profession, or investment in thinking about how this could be achieved, assessed or evidenced as an indicator of practice readiness. The aforementioned practitioner failings clearly indicate that digital knowledge gaps in social work education and practice both exist and persist. The fact that the newly developed Knowledge and Skills Statements (KSS) (DfE, 2014; DoH, 2015) make minimal reference to digital capabilities confirms how social work remains divorced from practice realities in this respect. 
That being said, recent revisions to both the 'Quality Assurance Agency - Subject Benchmark Statements' (QAA) and the 'Standards of Proficiency' (SoPs) by the professional regulator (QAA, 2016; HCPC, 2017) herald a departure away from the more nebulous links previously made between social work and digitalisation. The QAA benchmark statements now require 'graduates in Social Work... [to be able] to use information and communication technology effectively and appropriately' and on qualification to have an 'understanding of the social impact of technology, including the constraints of confidentiality and an awareness of the impact of the 'digital divide' (QAA, 2016, p.21). They discuss the need for a 'diverse' range of teaching methods (QAA, 2016, p.22), and are clear that the responsibility for professional development is a 'shared' endeavour (QAA, 2016, p.7). Ultimately, although the onus for continuing professional development is placed with the individual both during and post qualification (QAA, 2016, p.22). The revisions made to the SoPs by the Health Care Professionals Council (HCPC) align closely with the changes made by the QAA, in that they now require registrants to 'demonstrate a level of skill in the use of information technology appropriate to their practice' (HCPC, 2017, p.13). Furthermore, the regulator advises that these revisions have been made to reflect what practitioners 'should know, understand and be able to do when they complete their social work training' and make the point that 'once registered social workers must continue to meet the standards' (HCPC, 2017, np). What all of these revisions prompt is a review of curriculum content and delivery methods, in pre and post qualifying education, to determine whether or not they afford students and practitioners with opportunities to bridge digital knowledge gaps. Therefore ensuring that professional development reflects 'changes in practice' (HCPC, 2016, p.37).

It was the abovementioned practitioner failings and the sparseness of concrete guidance pertaining to digital professionalism, that triggered a qualitative research project aimed at 
'examining the contribution of social work education to the digital socialisation of students in readiness for practice' (Taylor, 2015). More specifically, this small-scale 'phenomenographic' (Marton, 1986, p.28) study was developed to explore students' experiences of technologies within their professional training. To understand if teaching and learning experiences were having an effect on digital competence and confidence and-or preparing them to address digitally orientated practice issues. Furthermore, it aimed to scrutinise if the interface between technologies and students could be exploited, and to evaluate the junctures in the curriculum where digital knowledge exchanges might occur. Overall, it sought to ascertain if curriculum design, content and delivery could be said to align with what might be expected of social work in the digital age. Given the very real need for tangible guidance that supports the development of digital literacies in social work, it was also thought that this work would provide an opportunity to glean understandings that could further inform existing professional requirements (QAA, 2008; HCPC, 2012; TCSW, 2013; KSS, 2014, KSS, 2015; QAA, 2016; HCPC, 2017).

The study, located within a School of Social Work, involved 11 finalists from various qualifying programmes. Participants were asked to reflect upon exposure to technologies throughout the course of their professional training and to discuss whether or not, they felt equipped to practice in the digital age. The interview method included the use of White's (2014, as cited in JISC, 2014) 'Visitor and Resident' mapping tool (np) Figure 1. An approach incorporated to focus participants thinking with regards to their digital presence and use of technologies within the personal and professional spheres. 


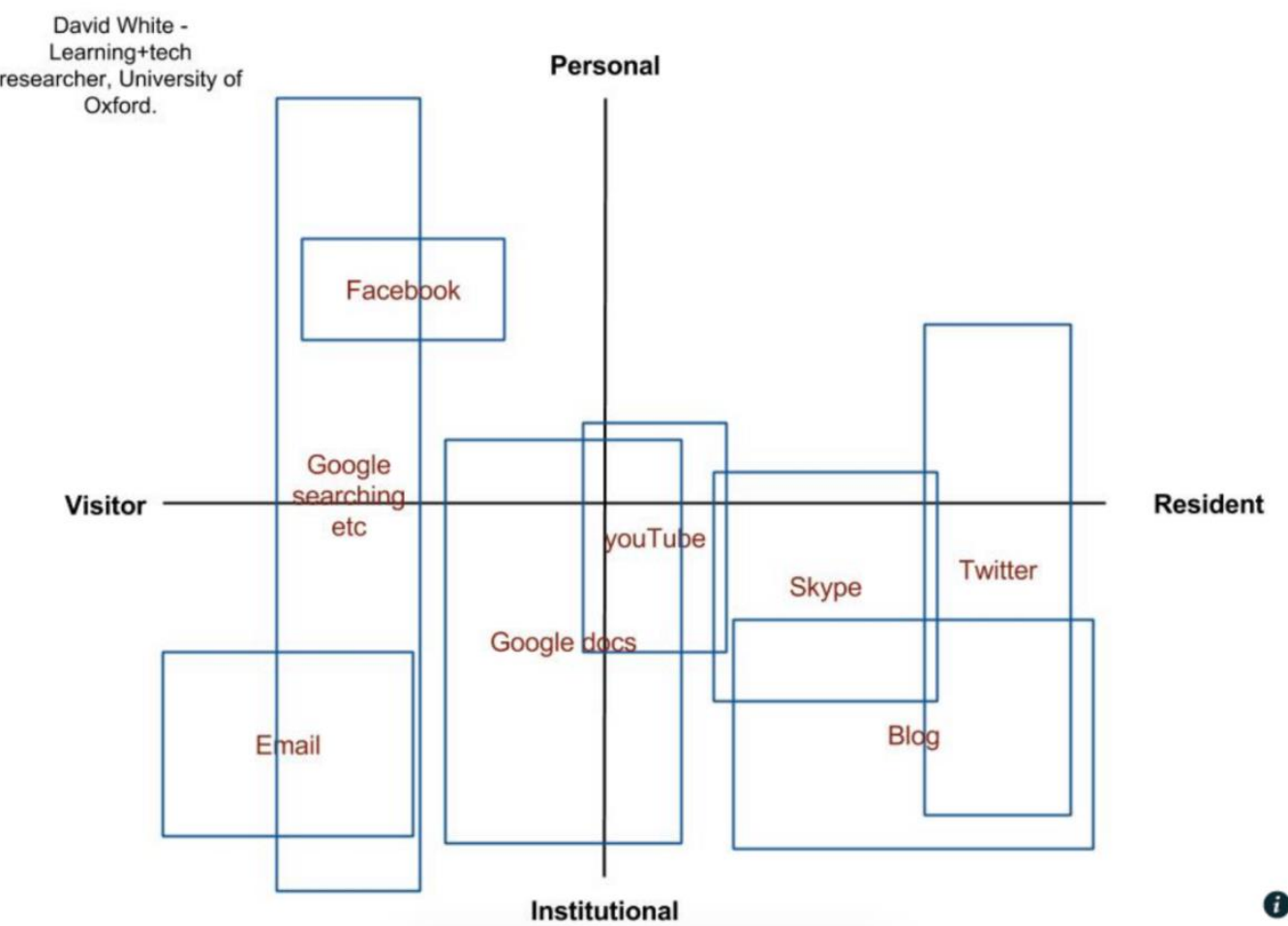

Figure. 1 Taken from White (2014, as cited in JISC, 2014, np) with permission.

This mapping device was originally developed as a way of encouraging students engaged in post compulsory education to reflect upon their digital usage, presence and behaviours online. Even though it was not originally designed as a research tool, given both the digital and the reflective orientations of this resource, it was felt that employing it in this way would generate insights on which the remainder of the semi-structured interviews could be built.

Early findings from the study suggest that even within a technology saturated teaching and learning environment, pointed exposure to digital technologies does not always occur, and that when it does, it is not always obvious. They also show that curriculum content does not explicitly support digital literacy development; and that students are not familiar with the term digital professionalism or view it as overtly relatable to their socialisation into the profession. What also became clear was the fact that none of the participants could recall if they had consciously reflected upon their use of technologies prior to the research interviews. 
Nor were they aware of two key documents produced to assist practitioners to consider online behaviours and practices (BASW, 2012; HCPC, 2012). Yet what is interesting, and just starting to emerge from the data, are indicators that learning about values and ethics more broadly appears to have inadvertently influenced digital presence and behaviours online. Participants were unable to articulate how this had occurred, with comments such as, 'I just do', 'It just has', 'I don't really know why' and 'I haven't thought about it before or until now' given in response to gentle probing where indicators of digital competence were noted. These indicators took various forms, with some students explaining how they had amended privacy settings on social media sites, some had removed identifying photographs from web profiles, and others described behaviours that signified that they were on occasions making, or at least becoming aware of, the need to make informed decisions about their presence and behaviours online. Whilst the study evidences a range of prior technology exposure across the participant group, early findings suggest that these students will enter the profession with digital knowledge and skills that fall short of what is, and what will be required, as technologies and the problems associated with them advance. There is little to suggest that this will not be the case for the majority of students across the population given that compulsory and post compulsory education systems do not, as yet, take a consistent approach to the development of digital literacies of learners (Kellsey and Taylor, 2016).

This then leads to questions about what professional socialisation in social work education should involve, and how digital capabilities can be developed in a way that enables students to demonstrate readiness for practice in the digital age (HCPC, 2017). If it is as Weiss et al. (2004) suggest that, 
'one of the attributes of any profession is the existence of an obligatory and specialized education and training system that serves as a necessary condition for entrance into the profession' (p.14)

then digitalisation needs to be aligned more clearly within requirements that shape social work education. However, this is not straightforward, as reflected by Millar (2013) whose research deduced that 'though historically regarded as essential, little is known about what professional socialization in social work actually looks like... how it occurs and what components are most critical' (p.368-369). The fact that the research subjects in this study struggled to recall learning activities or curriculum content that could have contributed to the progression of digital professionalism, authenticates Millar's findings and supports her claim that 'professional socialization... [can] involve the intended and unintended consequences of an educational program' (2013, p.369). Understanding more about what appears to have been 'unintended' digital development in this study will be significant to determining what the curriculum should include and how it should be delivered in future terms.

In a bid to understand digital literacy as a layer of professionalism in social work, Actor Network Theory (ANT) is being utilised as a lens through which to identify the elements within this social work education network that together make up the whole. To identify the 'human and non-human actants' (Ballantyne, 2015, p.106) and to examine the relationality of their existence in a manner that could explain how digital learning, in this instance, took place. ANT was originally designed as a medium through which interactions between people and technologies could be mapped, investigated and therefore understood (Latour, 2005). It pays attention to human and non-human actors in a way that recognises the agency of both, and in doing so, it provides a framework for understanding the functionality of a network. At 
this early stage of data analysis, the network appears to include the student, academics, the curriculum, teaching activities, professional requirements and a range of technologies.

Further analysis of the data, in keeping with the phenomenographic approach, will focus on the 'similarities and differences' in the 'collective' experiences of the subjects to construct an 'outcome space' made up of 'categories of description' (Akerlind, 2005, p.322 - 323). This method of data analysis aims to generate knowledge that will inform the curriculum in a way that can better prepare students for practice in the digital age. Integral to this is the notion of digital professionalism, that once acquired could reduce the likelihood of practitioners falling foul of the complexities of the networked age. However, it is worth bearing in mind as Ingerman \& Collier-Reed (2011) explain,

'what it is that is required in order to be considered technologically literate remains difficult to articulate as there is no one universal set of requirements that satisfies technological 'literateness' (p.138).

\section{Digital professionalism, social work and the connected age}

Social work education is the context within which preparedness for practice occurs; it is the gateway through which qualification and continuing professional development is secured. Yet, notable is the fact that the social work profession continues to get into difficulties online and that students can struggle to articulate digital development on qualification, suggesting therefore that the profession has not engaged sufficiently with digitalisation thus far. The emerging practice dilemmas, woven throughout this work, evidence the need for practitioners who can differentiate between technology usage that is 'empowering and human-centred' and that which is 'divisive and dehumanising' (Schwab, 2017, p.2). It is for this reason that the term 'digital professionalism' is used within this work, intended to address the 
'disjointedness' described by Rafferty (2014, as cited in Westwood, 2014, p.ix) above. It could be argued that professionalism, as a way of being, should be evident in everything that educators, practitioners and students do, but until such times as social work can consistently demonstrate digital as integral it is useful to set it apart. This is of course counter to the ideal explained by Jurgenson (2012), but clearly needed until the digital becomes 'enmeshed' (p.83) within a unified set of professional requirements designed to reflect the actuality of practice in the digital world. The point being that digital professionalism in social work can no longer be left to chance or to the unintended learning that the aforementioned study seems to suggest.

At no other point in human history has technological innovation oscillated so acutely between being a thing of 'great promise... [or that of] potential peril' (Schwab, 2017, p.2). Having a deep appreciation of this will be useful to social work as navigates the idea of practice readiness in the connected age. Whilst we pause however, to consider digitalisation and professionalism in social work, technological innovation continues to forge ahead. Given that we were, to a larger extent, 'caught unprepared by the mobile revolution' (Cooner, 2010, p.742) our preparedness for a future that includes big data, artificial intelligence, robotics and automation, needs further explored If we do not take steps to bridge digital knowledge gaps in social work future generations will have good reason to

'hold us responsible' (Susskind and Susskind, 2015, p.307).

\section{Bibliography}

Adler, M. (2016). A New Leviathan: Benefit Sanctions in the Twenty-first Century. Journal of Law and Society, 43, pp. 195-227. 
Akerlind, G.S. (2005). Variation and commonality in phenomenographic research methods. Higher Education Research \& Development, 24(4), pp. 321-334.

Ballantyne, N. (2015). Human Service Technology and the Theory of the Actor Network. Journal of Technology in Human Services, 33(1), pp 104-117.

Bradshaw, P. (2016). I Daniel Blake Review: Ken Loach's quiet rage against injustice. [Guardian] Retrieved from https://www.theguardian.com/film/2016/oct/20/i-daniel-blakereview-ken-loach-film-benefits-system

British Association of Social Workers (BASW) (2012). BASW Social Media Policy.

Retrieved from http://cdn.basw.co.uk/upload/basw_34634-1.pdf

Cooner, T.S. (2010). Preparing for ICT Enhanced Practice Learning Opportunities in 2010: A Speculative View. Social Work Education, 23(6), pp. 731-744.

Department of Education (DoE) (2014). Knowledge and Skills for Child and Family Social Work. Retrieved from

https://www.gov.uk/government/uploads/system/uploads/attachment_data/file/338718/14073

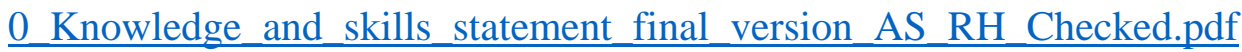

Department of Health (DoH) (2015). Knowledge and Skills Statement for Social Workers in Adult Services. Retrieved from www.gov.uk/government/uploads/system/uploads/attachment_data/file/411957/KSS.pdf ECORYS UK (2016). Digital Skills for the UK Economy. Retrieved from https://www.gov.uk/government/uploads/system/uploads/attachment_data/file/492889/DCM $\underline{\text { SDigitalSkillsReportJan2016.pdf }}$

Fenwick, T (2016). Social media, professionalism and higher education: a sociomaterial consideration. Studies in Higher Education, 41(4), pp.664-677.

Gov. UK (2012). Digital Efficiency report. Retrieved from https://www.gov.uk/government/publications/digital-efficiency-report/digital-efficiencyreport

Gov. UK (2016). Digital by Default Service Standard. Retrieved from https://www.gov.uk/service-manual/digital-by-default 
Harlow, E. \& Webb, S. A. (2003). Information and Communication Technologies in the Welfare Services. London: Jessica Kingsley Publishers.

Health and Care Professions Council (2016). Guidance on conduct and ethics for students. Retrieved from http://www.hpc-

uk.org/assets/documents/10002C16Guidanceonconductandethicsforstudents.pdf

Health Care Professions Council (2017). Standards of Proficiency - Social Workers in England. Retrieved from http://www.hcpc-uk.org/publications/standards/index.asp?id=569 Ingerman, A. \& Collier-Reed, B. (2011). Technological literacy reconsidered: A model for enactment. International Journal of Technology and Design Education, 21(2), pp. 137-148. Jurgenson, N. (2012). When atoms meet bits: Social media, the mobile web and augmented revolution. Future Internet, 4(1), pp. 83-91.

Kellsey, D. \& Taylor, A. M. L. (2016). The LearningWheel: a model of digital pedagogy. St Albans: Critical Publishing Ltd.

Latour, B. (2005). Reassembling the social: An introduction to actor-network-theory. Oxford: Oxford University Press.

Lightbody, B. (2015). The i-learning revolution: A new pedagogy. Batley: Collegenet Publications Limited.

Marton, F. (1986). Phenomenography — a research approach to investigating different understandings of reality. Journal of Thought, 29(3), pp. 28-49.

Meyer, J. \& Land, R. (2003). Threshold Concepts and Troublesome Knowledge: Linkages to Ways of Thinking and Practising within the Disciplines, Enhancing Teaching-Learning Environments in Undergraduate Courses Project Occasional Report 4. Retrieved from http://www.etl.tla.ed.ac.uk

McNicoll, A. (2016). Social worker who used Facebook to communicate with service user suspended. [Community Care] Retrieved from http://www.communitycare.co.uk/2016/11/30/social-worker-facebook-messaged-serviceuser-suspended/ 
National Crime Agency (2012). Live online child abuse - 29 international arrests made.

Retrieved from http://www.nationalcrimeagency.gov.uk/news/312-live-online-child-abuse29-international-arrests-made

NSPCC (2016). What children are telling us about bullying. London: NSPCC.

Office of National Statistics (2016). Internet users in the UK: 2016. Retrieved from https://www.ons.gov.uk/businessindustryandtrade/itandinternetindustry/bulletins/internetuser $\underline{\mathrm{s} / 2016}$

Ogunyankin, F. \& Tudor, P. (2016). Sunderland Safeguarding Children's Board. Serious case review Young Person I. Retrieved from https://goo.gl/cqXlbl

Pasha-Robinson, L. (2016). Teenager killed herself in front of parents after 'relentless' cyber bullying [Independent]http://www.independent.co.uk/news/brandy-vela-cyber-bullying-kill$\underline{\text { shoot-herself-driven-suicide-texas-shotgun-a7451446.html }}$

Peel, M. \& Shorrock, T. (2016). An Analysis of Serious Case Reviews For Sunderland SSCB: Taking a 'joined-up' look at the Lessons to be Learnt - Young Person I and Young Person K. Retrieved from https://goo.gl/MyluY7

Quality Assurance Agency (QAA) (2008). Revised Subject Benchmarks - Social Work. Retrieved from http://www.qaa.ac.uk

Quality Assurance Agency (QAA) (2016). Subject Benchmark Statement - Social Work. Retrieved from http://www.qaa.ac.uk/en/Publications/Documents/SBS-Social-Work-16.pdf Rafferty, J. (1997). Shifting paradigms of information technology in social work education and practice. The British Journal of Social Work, 27(6), pp. 959-969.

Rafferty, J. \& Waldman, J. (2006). Fit for Virtual Social Work Practice? Journal of Technology in Human Services, 24(2/3).

Rettie, R. (2004). Using Goffman's frameworks to explain presence and reality. Presence 2004: Seventh Annual International Workshop, pp. 117-124. Valencia, ISPR.

Richardson, H. (2017). Robots could help solve social care crisis, say academics. Retrieved from http://www.bbc.co.uk/news/education-38770516 
Rust, E. (2014). When the UK goes 'digital by default', who will be left behind? [Guardian] Retrieved from https://www.theguardian.com/technology/2014/jun/23/when-the-uk-goesdigital-by-default-who-will-be-left-behind

Sage, M. \& Quinn, A. (2014). The Use of Technologies in Human Service Education and Training. Journal of Technology in Human Services, 32(1), pp. 1-3.

Schraer, R. (2014). Social worker who sent 'offensive' tweets to David Cameron found fit to practise. [Community Care] Retrieved from

http://www.communitycare.co.uk/2015/08/11/social-worker-sent-offensive-tweets-davidcameron-found-fit-practise/

Schwab, K. (2017). The fourth industrial revolution. London: Penguin.

Stevenson, L. (2014). HCPC sanctions social worker over Facebook posts. [Community Care] Retrieved from http://www.communitycare.co.uk/2014/09/10/social-worker-givenconditions-practice-order-disrespectful-facebook-posts/

Stevenson, L. (2016a). Was decision to expel social work student for Facebook posts draconian or deserved? [Community Care] Retrieved from

http://www.communitycare.co.uk/2016/03/02/decision-expel-social-work-student-facebookposts-draconian-deserved/

Stevenson, L. (2016b). Social workers 'not equipped' to identify risks of social media, reviews say: Serious case reviews into the deaths of two teenage girls found that social media played a "very significant" role in the girls' vulnerability. [Community Care] Retrieved from http://www.communitycare.co.uk/2016/09/15/social-workers-equipped-identify-risks-socialmedia-reviews-say/

Susskind, R.E. \& Susskind, D. (2015). The Future of the Professions: How Technology Will Transform the Work of Human Experts. Oxford: Open University Press.

Taylor, A.M.L. (2015). Exploring the contribution of social work education to the digital socialisation of students for practice in the digital age [Google Doc] Retrieved from https://drive.google.com/open?id=0B2Q7-K-y7OQhVkxielVpYWY5ZWM

Taylor, A.M.L. (2017). The Unintended Impacts of I Daniel Blake. [Blog] Retrieved from http://wp.me/p3Nid6-4G 
The College of Social Work (TCSW) (2013). Curriculum guides for qualifying social work education. Retrieved from

www.collegeofsocialwork.org/standard2colrhm.aspx ?id=50\&terms=Curriculum\%20Guides

Turner, D. (2016a). Lack of clear social media guidance is creating 'anxiety and alienation'. [Community Care] Retrieved from http://www.communitycare.co.uk/2015/04/29/lack-clearsocial-media-guidance-creating-anxiety-alienation/

Turner, D. (2016b). How we prepared social work students for appearing in court.

[Community Care] Retrieved from http://www.communitycare.co.uk/2016/10/05/prepared-

social-work-students-appearing-court/

Wakefield, J. (2016). Is your child a cyberbully and if so, what should you do? Retrieved from http://www.bbc.co.uk/news/technology-38529437

Weiss, I., Gal, J. \& Cnaan, R. A. (2004). Social Work Education as Professional

Socialization: A Study of the Impact of Social Work Education Upon Students' Professional Preferences. Journal of Social Service Research, 31(1), pp. 13-31.

Westwood, J. (2014). Social Media in Social Work Education. Herefordshire: Critical Publishing.

White, D. (2014). Example visitor and resident maps. In JISC Evaluating Digital Services. Retrieved from https://www.jisc.ac.uk/guides/evaluating-digital-services/example-visitorand-resident-maps

Whitehead, J. (2013), Cyberbullying resulting in suicides. Retrieved from https://www.google.co.uk/url?sa=t\&rct=j\&q=\&esrc=s\&source=web\&cd=9\&ved=0ahUKEwj $\underline{7 q--8 y-}$

LTAhX1DcAKHaBGDgYQFghSMAg\&url=http\%3A\%2F\%2Fwww.eani.org.uk\%2F_resourc es\%2Fassets\%2Fattachment\%2Ffull\%2F0\%2F41628.pdf\&usg=AFQjCNGimdrz1hyG_raHZikkBfvKZ0xA\&sig2=ptTsyR01kc5j5kpjNo_6Sw\&cad=rja 